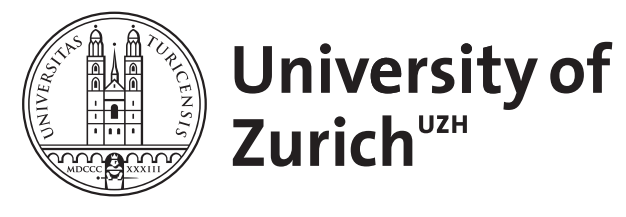

\title{
European unification: a new proposal
}

Frey, Bruno S

\begin{abstract}
My contribution presents a possibility to unify Europe based on newly emerging political units focused on solving problems rather than on historically given nation states. These Endogenous Political Entities (EPE), as they shall be called, are better suited to reach the goals of European unification as they strengthen the fundamental European values of variety and freedom. I make three propositions: to base the unification of Europe on nation states is unfortunate as the latter are responsible for the political disaster of the two World Wars; the unification must proceed in a problem-oriented manner. The constitution of Europe must allow and promote EPE to emerge specifically to deal with particular problems; the new political units can be introduced in marginal steps. Over time, a flexible and dynamic net of political entities will arise taking care of the large economic, social and cultural diversity in Europe
\end{abstract}

DOI: https://doi.org/10.1007/s10602-013-9147-6

Posted at the Zurich Open Repository and Archive, University of Zurich

ZORA URL: https://doi.org/10.5167/uzh-156521

Journal Article

Published Version

Originally published at:

Frey, Bruno S (2013). European unification: a new proposal. Constitutional Political Economy, 24(4):285294.

DOI: https://doi.org/10.1007/s10602-013-9147-6 


\title{
European unification: a new proposal
}

\author{
Bruno S. Frey
}

Published online: 16 November 2013

(C) Springer Science+Business Media New York 2013

\begin{abstract}
My contribution presents a possibility to unify Europe based on newly emerging political units focused on solving problems rather than on historically given nation states. These Endogenous Political Entities (EPE), as they shall be called, are better suited to reach the goals of European unification as they strengthen the fundamental European values of variety and freedom. I make three propositions: to base the unification of Europe on nation states is unfortunate as the latter are responsible for the political disaster of the two World Wars; the unification must proceed in a problem-oriented manner. The constitution of Europe must allow and promote EPE to emerge specifically to deal with particular problems; the new political units can be introduced in marginal steps. Over time, a flexible and dynamic net of political entities will arise taking care of the large economic, social and cultural diversity in Europe.
\end{abstract}

Keywords Europe - European Union · European integration

JEL Classification $\mathrm{F} 5 \cdot \mathrm{P} 16 \cdot \mathrm{P} 48 \cdot \mathrm{B} 52 \cdot \mathrm{D} 02$

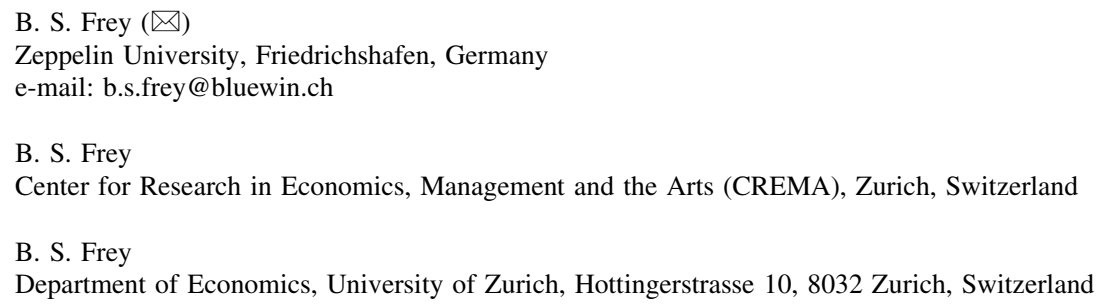




\section{Unification by nation states}

The European unification, which led to the formation of the European Union (EU), is firmly based on territorial nation states. This statement is obvious and taken as a matter of fact. The foundation on nation states applies not only to how the present institutional arrangements work but also to how the future development is envisaged. Thus, in September 2012, the "Future of Europe Group" of eleven foreign ministers of the EU promulgated "A New Vision of Europe". It issued a report suggesting that the future European integration be achieved by strengthening the Union relying on existing nation states (Sikorski and Westerwelle 2012). At the same time and in a similar vein, the President of the European Commission, José Manuel Barroso, publicized a "Plan for a Federation of Nation States" (EU Commission 2012).

To outsiders, such plans appear surprising because the EU is currently in its deepest crisis since the Treaty, or rather the Constitution, of Rome was signed in 1958. The creation of the euro-which is considered an essential element of the European integration ${ }^{1}$ - has led to huge fiscal deficits in various nations, in particular in Greece and Cyprus. Only the extreme increase in the money supply by the European Central Bank, which buys government bonds in an unprecedented scale, has up to now (June 2013) been able to prevent the bankruptcy of several EU member countries. One would have expected a discussion of alternatives to the present construction of the EU. Yet neither politicians nor (with few exceptions) scholarly observers of the European unification process consider the possibility of unifying Europe along different lines. Rather, both EU and national politicians rely on the principle of "more of the same", namely, to seek an "ever closer union" built on the European nation states. A small number of other politicians, especially in the United Kingdom, want to have "less of the same". Again this is on the same axis of the traditional integration of the nation states.

This contribution presents a possibility to unify Europe based on newly emerging political units focused on solving problems rather than on historically given nation states. These Endogenous Political Entities (EPE), as they shall be called, are better suited to reach the goals of European unification as they strengthen the fundamental European values of variety and freedom.

My proposal can be summarized in three propositions:

1. To base the unification of Europe on nation states is unfortunate as the latter are responsible for the political and human disaster of the two World Wars.

2. The unification must proceed in an issue-oriented manner. They cannot be solved within the context of nation states whose borders have been formed by many historical flukes. The constitution of Europe must allow and promote issue-orientated EPE with extensive fiscal competencies to emerge specifically to deal with these problems.

\footnotetext{
1 The statement by German Chancellor Merkel, that "If the euro falls, the EU falls, and then falls Europe", is noteworthy.
} 
3. The new political units can be introduced in marginal steps. Over time, a flexible and dynamic net of political entities will arise taking care of the large economic, social and cultural diversity in Europe.

The integration of Europe has been directed at two major goals. On the one hand the peace project seeking to overcome the wars among nation states; on the other hand the economic project of establishing free trade between the European nations. The question is whether the existing constitution of the EU can reach these two objectives.

\subsection{Peace in Europe}

The emergence of the concept of nation states in the nineteenth century can be considered a sign of progress. Most importantly, the nation states incorporated the idea of a constitution establishing the division of power between parliament, executive and jurisdiction, and guaranteeing the rule of law and basic individual and human rights. In contrast, in the twentieth century the nation states were involved in two catastrophic World Wars. The First World War cost the lives of 10 million soldiers, and the terrible conditions of trench warfare are still in vivid memory. In addition, a large number of civilians were killed. The Second World War was even more terrible. It is estimated to have cost 60 million lives, among them many civilians. More recently, the military forces of the EU member states were not mobilized appropriately to prevent humanitarian catastrophes during the Yugoslav Wars in the 1990s.

Far-sighted politicians such as Robert Schumann, Jean Monnet, Alcide De Gasperi, and Luigi Einaudi envisaged and started a peace project designed to effectively prevent future wars in Europe. Winston Churchill joined in when, in his talk at the University of Zurich (19 September 1946), he postulated "Let Europe arise!" Unfortunately, and for an English person uncharacteristically, he used the expression "United States of Europe". Even such a great thinker does not seem to have seen any alternative to unifying Europe except by binding the nation states more closely together.

Charles De Gaulle's France and Konrad Adenauer's Germany created the prerequisites for European institutions designed to secure peace among nation states. The two great statesmen were children of their time as they took for granted that nation states would be the fundamental units.

The European peace project is seemingly a great success. Nevertheless, four important problems need to be pointed out:

- European politicians and adherents claim that the unification process has secured peace at least among its members. It may, however, as well be argued that the European unification process was possible only because France and Germany resolved their animosities. The causal direction is not as clear as often claimed.

- The European institutions did not contribute much if anything to solving intrastate conflicts resulting in such eruptions as outright civil wars in Northern Ireland and Spain. 
- The EU institutions are marked by a strong democratic deficit (see e.g. Rohrschneider 2002). The Economist (2012) titled an article "An ever-deeper democratic deficit", therewith poking fun at the former Commission President Jacques Delor's concept of an "ever-deeper European integration" (see Dinan 2005). However, the EU cannot be considered a democratic political institution able to serve as an example for the twenty-first century. It clearly is an elite project from which the citizens have been largely excluded.

- The EU has a major image problem. Indeed, the support for the European institutions has been strongly falling over time.

The political unification process of the EU therefore is somewhat less shiny than it seems at first sight.

\subsection{Free trade in Europe}

The second European project is economic and can be considered a great achievement. The harmonization was intended to increase competition between nationally protected suppliers or closed markets. The creation of a common market has indeed strongly reduced trade barriers between nation states, eliminating them in many regards. This progress has, however, been accompanied by high costs accruing in three different ways:

- The EU bureaucracy in Brussels has produced an immense number of regulations and directives. The British think tank Open Europe estimates that the legal norms issued since 1957 cover 667,000 pages. As of today, 170,000 are in force, of which 100,000 were produced over the last 10 years. Piling up this "acquis communautaire" leads to a stack of $44 \mathrm{~m}$, comparable to the height of the Nelson column on Trafalgar Square.

- Harmonization and therefore uniformity in many parts of the economy crowded out competition (Vaubel 2008). There is thus a particular loss in system competition (Van den Bergh 2000). Liberally minded economists such as Wilhelm Roepke fervently warned of such a centralization in Europe as it reduces freedom.

- Potential new entrants into the EU have no option than to accept the entire "acquis communautaire" - as if the existing legal rules were sacred and the only possibility for unifying Europe.

Another point is indirectly related to the above-mentioned aspects. The monetary union is supposed to ease trade among the EU member countries. The introduction of the euro was a political act of which many economists had warned. As a result grave conflicts between member states erupted. Commentators speak of a "Europe of strife" instead of a "Europe of peace". It is ironic that the politically enforced introduction of the euro has in fact hampered good relationships among EU countries.

\section{A Europe of diversity}

A Europe different from the existing EU institutions can be envisaged: a Europe furthering, rather than hindering, the cultural, political and economic diversity for 
which Europe stands. To reach this objective, new political entities are required which focus on the problems to be solved. What matters are the issues and not the historically given political borders. This new kind of unification better serves the European ideal than the distinctly national and bureaucratic integration presently undertaken by the EU.

\subsection{Endogenous Political Entities (EPE)—Basic Set-up}

It stands to reason that the problems and conflicts to be solved are first to be identified before the appropriate political units can be formed. It is thus suggested to reverse the procedure currently pursued of treating issues within the existing political borders. The political boundaries should endogenously be adjusted such that the problems can be solved as efficiently as possible. Depending on the issues in question, these entities can be smaller or larger than the existing nation states. It is only by chance that a nation state has a territorial extension suited for the issue at stake. Normally, they are either too large or too small, and many parts are unrelated to the issue, while territories involved are part of another nation state. These EPE differ from the existing regions defined by EU politicians and bureaucrats because the borders of the latter are largely the result of historical processes.

Political Economy teaches us that local political decisions are preferable as they induce a stronger incentive to compare the benefits and cost of alternative solutions. The population engages politically the more intensively and the more competently the better informed they are about the issues at hand (see Congleton 1997, 2000). The newly emerging EPE should have such a territorial extension that they minimize the aggregate costs of spillover effects on other units and of decisionmaking.

Endogenous Political Entities are characterized by three properties. They start from existing issues (they are endogenous), they serve the interests of the citizens affected (political), and they constitute special purpose associations (entities).

\section{Endogenous}

- EPE emerge in reaction to existing problems and conflicts and are not dependent on the historical borders of existing communities.

- EPE arise and are organized from below and are not to be imposed from above.

- Depending on the issue EPE can be formed by individuals, parts of existing political units (e.g. city districts), communes, regions, or even nations (Vanberg 2000).

\section{Political}

- In a modern and forward-looking world the EPE must be democratically organized and legitimized. The citizens affected need not only be able to elect their representatives by going to the polls or by postal service, but also by electronic voting. The lower participation cost induces citizens to become better informed and to engage more intensively (But see Hodler et al. 2012). Moreover, popular referenda are to be used to resolve issues of content. 
- The emerging entities must have far-reaching fiscal autonomy, i.e. they must be able to determine themselves expenditures and raise the necessary taxes to fulfill their tasks.

- The various EPE may be in competition with each other. It is always possible to challenge an existing EPE by founding a new, more efficient entity.

\section{Entities}

- The newly emerging units can be private, public, or any mixture of the two. EPE do not solely consist of government institutions. For example, Chinese people are present in the whole of Asia and increasingly in Europe and Africa. With respect to their language, culture and customs they constitute an entity going far beyond the People's Republic of China, and their interests often strongly deviate from the latter's official position. A similar diaspora with political weight are the Jews or the Kurds. In all these cases the existing political units cannot adequately cater for the problems and conflicts with which these persons are confronted.

- Entry and exit need to be flexible in order to allow EPE to adjust to changing conditions. Rules are required which are to be agreed on at the constitutional level, i.e. behind the veil of ignorance. Exit charges can be introduced when a member of an EPE benefitted from a capital gain. For instance, if a person was able to increase his or her human capital due to the provision of corresponding educational facilities, an exit charge is in order. Entry charges can be imposed when joining an EPE leads to a capital gain. Flexibly arranged rules for exit and entry produce a competitive situation. Efficient EPE benefit at the cost of inefficient ones.

\subsection{Endogenous Political Entities (EPE)_Problem solving examples}

Endogenous Political Entities are not only a theoretical speculation. Rather, they are able to cope with actual problems. These are some examples illustrating this claim:

- The departing and incoming flights at Zurich airport produce noise in various geographical regions belonging to different Swiss cantons and German counties (Landkreise). Currently, the ensuing problems are addressed in a cumbersome and ineffective way by the nation states though the respective decision makers in Bern and Berlin are far away from the problems. An EPE extending over the area affected by the aircraft noise and going beyond the borders of existing countries would provide a markedly more effective organizational unit.

- Traffic through the Alps only affects some areas of Europe while for other areas it is largely irrelevant. An EPE straddling parts of several nations, such as Slovenia, Croatia, Austria, Italy, Germany, Switzerland and France, is able to successfully address the ensuing problems. In contrast, many other parts of Europe, say Portugal or Finland, are unaffected.

- Many tourism regions go beyond existing national boundaries. A pertinent example is the area around Lake Constance involving parts of Germany, Austria and Switzerland as well as parts of the respective lower political units such as 
Baden-Württemberg, Bavaria, Vorarlberg, St. Gallen, Thurgau and Schaffhausen. An EPE is able to focus on the problems and issues relevant for this region.

- Turkey presently aspires to becoming a member of the EU but its entry is subject to considerable controversy. Parts of Turkey could easily and immediately join various EPE, in particular those relating to economic issues. Neither the EU nor Turkey would have to reach an unsatisfactory compromise on problems in which there are fundamentally different positions (such as, for instance, women's rights). There is no need for Turkey to accept the full "acquis communautaire". Similar procedures are possible for the North-African nations Morocco, Tunisia, Algeria and Libya, some of whose cultural norms and political institutions at present are not acceptable for the countries in the EU. At the same time a closer association with Europe is most desirable and can be achieved by having parts of these countries join particular EPE.

- The concept of EPE allows those parts of member states of the EU wishing to have a larger measure of independence from their respective nation states to reach goals important to them. Terrorist activities such as those having taken place in the Basque Country, Catalonia, Northern Ireland or Corsica can thereby be attenuated.

Endogenous Political Entities can learn from international firms. The latter have overcome many of the organizational issues faced by nation states. They adopt flexible units within the firm created to solve specific problems. By necessity they are flexible and overlap (Kalleberg 2001; Eckel and Neary 2010).

Endogenous Political Entities expand the idea of special purpose associations or communes by providing a democratic basis. The latter normally are technocratically oriented and do not have any direct participation rights for citizens. EPE builds on various proposals to improve the functioning of state activity. The Functional Overlapping Competing Jurisdictions (FOCJ) (Casella and Frey 1992; Frey and Eichenberger 1996; Frey and Eichenberger 1999; Frey 2001; Eichenberger and Frey 2002; Kyriacou 2006), and related concepts (Vanberg and Kerber 1994; Congleton et al. 2003; Vanberg 2011) represent one particular form of organization, which may arise from EPE. Similar proposals are "Block Improvement Districts (BLIDS)" (Ellikson 1998), "artificial states" (Alesina et al. 2011) or "charter cities" (Romer 2010). Even more far-reaching is the idea of "seasteading" (Friedman and Taylor 2012). It proposes units totally independent from nation states. Seasteads are an assembly of ships located in the international sea. Each can determine its own constitution and allows easy entry and exit, therewith establishing brisk competition.

\section{Introducing endogenous political units}

Skeptics might argue that the EU is already institutionally so well established that the persons involved in it will reject the idea of EPE. No doubt, the established EU politicians and bureaucrats as well as the many national politicians who derive benefits from the EU have a strong incentive to dismiss EPE as they work directly 
against their interests (see Vaubel 1994). Such politicians and bureaucrats would lose an important instrument with which they can influence and determine the future European integration. Their power is diminished as the EPE emerge from below and can be manipulated less easily according to their interests. The idea of EPE will, of course, also be rejected by conservative thinkers committed to the notion of the unique sovereignty of nation states.

Nevertheless, for two reasons the idea of EPE has a chance of being implemented:

- EPE follow the original idea and institutional design of the European integration. France and Germany started the process by agreeing on a problem-oriented entity. In line with the European peace project, the European Coal and Steel Community was established based on the knowledge that wars cannot be undertaken without using steel and coal. This Community integrated in particular the German steel industry into a European context, thus making future wars between France and Germany virtually impossible. The European Atomic Energy Community (Euratom) can also be considered a problem-oriented institution in the sense of EPE.

- EPE can marginally arise within the existing structure of the EU. The idea of a "Europe à la carte" and a "Europe of different speeds" becomes a desired norm and not an aberration to fight against.

When EPE are successively introduced a natural process emerges which over time reduces the weight of the centralized-bureaucratic features of the EU and enables a dynamic and competitive net of political entities. This stepwise procedure need not abolish existing political units. However, the latter lose in importance compared to the newly emerging EPE. The new political entities help overcome the tendency of nation states to engage in wars. Empirical research (Vasquez 2009; Senese and Vasquez 2008) suggests that individuals are more inclined to fight and to die for their territory. The more intricate the net of overlapping and competing EPE is the more stable will be peace.

\section{Conclusions}

The European unification effectively started with the European Coal and Steel Community. Thereafter the political peace project and the economic free trade project were solely based on nation states. This means that a political institution was chosen which is significantly responsible for the catastrophic wars in the first part of the twentieth century.

This contribution suggests an alternative, which is able to emerge in parallel to the existing European institutions. The issues and problems to be solved must be the point of departure. For that purpose the adequate territorial units must be chosen without relying on the existing national boundaries. The EPE must be made possible in the European constitution but the initiative and the formation needs to come from below. To be able to meet these tasks, the EPE must have far-reaching fiscal autonomy, i.e. they must be able to determine themselves the necessary taxes and 
expenditures. Such a new orientation of the process of European integration is immediately feasible and relieves the existing nation states of conflicts otherwise difficult to overcome. EPE create a dynamic net of political units, which is consonant with European diversity.

Acknowledgments The author is grateful for helpful remarks to Geoffrey Brennan, Roger Congleton, Lars Feld, Jana Gallus, Barbara Krug, Viktor Vanberg, Richard Wagner, and excellent comments by two referees.

\section{References}

Alesina, A., Easterly, W., \& Matuszeski, J. (2011). Artificial states. Journal of the European Economic Association, 9(2), 246-277.

Casella, A., \& Frey, B. S. (1992). Federalism and clubs. Towards an economic theory of overlapping political jurisdictions. European Economic Review, 36, 639-646.

Congleton, R. D. (1997). Political efficiency and equal protection of the law. Kyklos, 50, 485-505.

Congleton, R. D. (2000). A political efficiency case for federalism in multinational states: Controlling ethnic rent seeking. In G. Galeotti, P. Salmon, \& R. Winthrobe (Eds.), Competition and structure (pp. 365-397). New York: Cambridge University Press.

Congleton, R. D., Kyriacou, A., \& Bacaria, J. (2003). A theory of menu federalism: Decentralization by political agreement. Constitutional Political Economy, 14, 167-190.

Dinan, D. (2005). Ever closer union: An introduction to european integration. Lynne Rienner: Boulder, Co.

Eckel, C., \& Neary, J. P. (2010). Multi-product firms and flexible manufacturing in the global economy. Review of Economic Studies, 77, 188-217.

Economist. (2012). An ever-deeper democratic deficit.

Eichenberger, R., \& Frey, B. S. (2002). Democratic governance for a globalized world. Kyklos, 55, 403-420.

Ellikson, R. C. (1998). New institutions for old neighborhoods. Duke Law Journal, 48, 75-110.

EU Commission. (2012). Towards a federation of nation states. 2012 State of the Union address by President Barroso. http://Ec.europa.eu/news_explained. Downloaded May 20, 2013.

Frey, B. S. (2001). A utopia? Government without territorial monopoly. Independent Review, 6, 99-112.

Frey, B. S., \& Eichenberger, R. (1996). FOCJ: Competitive governments for Europe. International Review for Public Economics, 16, 315-327.

Frey, B. S., \& Eichenberger, R. (1999). The New Democratic Federalism for Europe. Functional, overlapping and competing jurisdictions. Cheltenham: Edward Elgar.

Friedman, P., \& Taylor, B. (2012). Seasteading: Competitive governments on the ocean. Kyklos, 65, 218-235.

Hodler, R., Luechinger, S., \& Stutzer, A. (2012). The Effects of voting costs on the democratic process and public finances. Mimeo: Wirtschaftswissenschaftliches Zentrum, Universität Basel.

Kalleberg, A. L. (2001). Organizing flexibility: The flexible firm in a new century. British Journal of Industrial Organization, 39, 478-504.

Kyriacou, A. P. (2006). Functional, overlapping, competing jurisdictions and ethnic conflict management. Kyklos, 59, 63-83.

Rohrschneider, R. (2002). The democracy deficit and mass support for a EU-wide government. American Journal of Political Science, 46, 463-475.

Romer, P. (2010). Technologies, rules and progress. The case for charter cities. Washington, DC: Center for Global Development.

Senese, P. D., \& Vasquez, J. A. (2008). The steps to war: An empirical study. Princeton: Princeton University Press.

Sikorski, R., \& Westerwelle, G. (2012). A new vision of Europe. New York Times, September 17.

Van den Bergh, R. (2000). Towards an international legal framework of regulating competition in Europe. Kyklos, 53, 435-466.

Vanberg, V. J. (2000). Functional federalism: Communal or individual rights? Kyklos, 53, 363-386. 
Vanberg, V. J. (2011). Social dilemmas and self-organization in pre-defined and in self-selected groups. The Good Society, 20, 67-72.

Vanberg, V. J., \& Kerber, W. (1994). Institutional competition among jurisdictions: An evolutionary approach. Constitutional Political Economy, 5, 193-219.

Vasquez, J. A. (2009). The war puzzle revisited. New York: Cambridge University Press.

Vaubel, R. (1994). The public choice analysis of European integration: A survey. European Journal of Political Economy, 10, 227-249.

Vaubel, R. (2008). The political economy of labor market regulation in the European Union. Review of International Organization, 3, 435-465. 